\title{
PERAN KOMITE SEKOLAH DALAM PROSES MANAJEMEN MADRASAH PADA MADRASAH TSANAWIYAH NEGERI (MTsN) KARANG INTAN KABUPATEN BANJAR
}

\author{
Lathifah \\ MTsN Karang Intan \\ Jl. Sultan Sulaiman No. 04 Karang Intan Kab. Banjar Kalimantan Selatan \\ e-mail: mtsnkrgintan@gmail.com
}

\begin{abstract}
This research is executed as a mean to describe the role of school Committee toward madrasah's management process in Public Madrasah Tsanawiyah (MTsN) Karang Intan Banjar Regency, specifically on their role as advisory agency, supporting agency, controlling agency, and as a mediator. This research uses descriptive qualitative approach. Data collected with observation technique, documentation and interview toward school committee and teachers. This research's findings show that school committee have a important role in Madrasah's management process, especially in the management of facilities and infrastructure, finance, student affairs, curriculum, personnel, and public relations.
\end{abstract}

Keywords: school committee, madrasah's management process, Public Madrasah Tsanawiyah (MTsN)

Abstrak: Penelitian ini dilaksanakan sebagai cara untuk menggambarkan peran dari komite sekolah terhadap proses pengelolaan madrasah pada Madrasah Tsanawiyah Negeri (MTs) Karang Intan Kabupaten Banjar, terutama tentang peran mereka sebagai pemberi pertimbangan, memberikan dukungan, melakukan pengendalian, dan sebagai mediator. Penelitian in imenggunakan pendekatan deskriptif kualitatif. Data dikumpulkan melalui teknik observasi, dokumentasi, dan wawancara dengan komite sekolah dan para guru. Temuan dari penelitian ini menunjukkan bahwa komite sekolah memiliki peran yang penting dalam proses pengelolaan madrasah, terutama dalam mengelola fasilitas dan infrastruktur, keuangan, kemahasiswaan, kurikulum, personalia, dan hubungan kemasyarakatan.

Kata Kunci: komite sekolah, proses pengelolaan madrasah, Madrasah Tsanawiyah Negeri (MTs)

\section{Latar Belakang}

Madrasah / Sekolah dan masyarakat merupakan dua komunitas yang berkaitan dan saling melengkapi, bahkan dapat memberikan suatu warna terhadap perumusan model pembelajaran tertentu di sekolah dalam lingkungan masyarakat tertentu pula. Masyarakat merupakan sumber daya pendidikan yang tiada bandingnya bagi satuan pendidikan. Disekolah masyarakat dapat menjadi tumpuan atas peningkatan dan pelayanan mutu pendidikan dalam penyelenggaraan pendidikan.Tetapi pada dewasa ini, masih banyak penyelenggaraan pendidikan yang masih mengesampingkan partisipasi masyarakat sehingga penyelenggaraan pendidikan dimasa sekarang ini, menuntut adanya partisipasi masyarakat yang maksimal.

Dalam UU Nomor 20 tahun 2003, pada salah satu misinya dijelaskan agar memberdayakan masyarakat dalam penyelenggaraan pendidikan berbasis otonomi daerah dalam konteks Negara Kesatuan Republik Indonesia (NKRI), kemudian masyarakat berperan dalam peningkatan mutu pelayanan pendidikan yang meliputi perencanaan, pengawasan, dan evaluasi program pendidikan melalui dewan pendidikan atau Komite Sekolah. 
Menurut Peraturan Pemerintah Nomor 17 tahun 2010 tentang pengelolaan dan penyelenggaraan pendidikan, dinyatakan dalam pasal 188 ayat (2) bahwa peran serta masyarakat dirumuskan sebagai berikut.(a) Penyediaan sumber daya pendidik. (b) Penyelenggaraan satuan pendidikan. (c) Penggunaan hasil pendidikan. Pengawasan penyelenggaraan pendidikan, (e) Pengawasan pengelolaan Pendidikan, (f) Pemberian pertimbangan dalam pengambilan keputusan yang berdampak pada pemangku kepentingan pendidikan pada umumnya, dan / atau (g) Pemberian bantuan atau fasilitas kepada satuan pendidikan dan / atau penyelenggara satuan pendidikan dalam menjalankan fungsinya. Pemerintah melalui Keputusan Menteri Pendidikan Nasional No. 044/U/2002 tentang Dewan Pendidikan dan Komite Sekolah menjelaskan bahwa setiap satuan pendidikan diharuskan untuk membentuk komite sekolah di setiap satuan pendidikan. Komite sekolah diharapkan dapat meningkatkan kontrol terhadap kinerja satuan pendidikan dalam menjalankan setiap kebijakan pendidikannya.

Sebagai konsekwensi perluasan makna partisipasi masyarakat dalam penyelengaraan pendidikan pada setiap satuan pendidikan, maka diperlukan wadah yang dapat menampung dan menyalurkan pikiran dan gagasan dalam mengupayakan kemajuan pendidikan yang diberi nama Komite Sekolah. Dalam hal ini komite sekolah adalah badan mandiri yang mewadahi peran serta masyarakat dalam rangka meningkatkan mutu, pemerataan dan efisiensi pengelolaan pendidikan disatuan pendidikan, baik pada pendidikan pra sekolah maupun pendidikan dasar dan menengah. Dibentuknya komite sekolah dimaksudkan agar adanya suatu organisasi masyarakat yang mempunyai komitmen dan loyalitas serta peduli terhadap peningkatan kualitas sekolah.

Keberadaan komite sekolah sangat mendukung dalam penyelenggaraan pendidikan berupa materi maupun non materi. Dukungan yang dilakukan meliputi pemberian peningkatan sumber daya manusia, sarana dan prasarana yang berhubungan dengan pengadaan dan pemeliharaan beberapa fasilitas sekolah yang berkaitan dengan akademik maupun non akademik.

Alasan memilih Madrasah Tsanawiyah Negeri (MTsN) Karang Intan Kabupaten Banjar sebagai tempat penelitian didasarkan pada beberapa hal, yaitu: pertama, Madrasah Tsanawiyah Negeri (MTsN) Karang Intan Kabupaten Banjar merupakan satu-satunya madrasah negeri untuk tingkat SLTP di Kecamatan karang Intan. Kedua, prestasi akademik berdasarkan data yang ada menunjukkan bahwa tingkat kelulusan cukup baik dan sebagian besar melanjutkan kejenjang pendidikan berikutnya. Ketiga, kondisi fisik bangunan dari tahun ketahun sebagaimana yang ada dalam laporan program kerja tahunan dan berdasarkan observasi peneliti menunjukkan perkembangan yang cukup baik. Keempat, peneliti bertugas di madrasah ini dan mempunyai keinginan kuat untuk meningkatkan kualitas madrasah melalui pemberdayaan komite sekolah.

\section{Kajian Literatur}

Berdasarkan Keputusan Menteri Pendidikan Nasional Nomor 044/U/2000, konsep mengenai Komite Sekolah adalah badan mandiri yang mewadahi peran serta masyarakat dalam rangka peningkatan mutu, pemerataan, dan efisiensi pengelolaan pendidikan di satuan pendidikan, baik pada pendidikan pra sekolah, jalur pendidikan sekolah maupun jalur pendidikan luar sekolah. Nama badan disesuaikan dengan kondisi dan kebutuhan daerah masingmasing satuan pendidikan, seperti Komite Sekolah, Komite Pendidikan, Komite Pendidikan Luar Sekolah, Dewan Sekolah, Majelis Sekolah, Majelis Madrasah, Komite TK, atau nama lain yang disepakati.

Komite Sekolah berkedudukan di setiap satuan pendidikan, merupakan badan mandiri yang tidak memiliki hubungan hirarki dengan lembaga pemerintah (Hasbullah, 2007:90). Dalam UU Sisdiknas Nomor 20 tahun 2003 dijelaskan bahwa Komite Sekolah adalah lembaga mandiri yang beranggotakan orang tua/wali peserta didik, komunitas sekolah, serta tokoh masyarakat yang peduli pendidikan. 
Menurut Rusman (2008:512), Komite Sekolah adalah badan mandiri yang mewadahi peran serta masyarakat dalam rangka peningkatan mutu, pemerataan, dan efisiensi pengelolaan pendidikan di satuan pendidikan baik pada pendidikan pra sekolah, jalur pendidikan sekolah, maupun jalur pendidikan luar sekolah. Nama badan disesuaikan dengan kondisi yang ada dan kebutuhan masing-masing satuan pendidikan, seperti Komite Sekolah, Komite Pendidikan, Komite Pendidikan Luar Sekolah, Dewan Sekolah, Majelis Sekolah, Majelis Madrasah, atau nama lain yang disepakati.

Berdasarkan beberapa pengertian tentang komite sekolah tersebut, dapat disimpulkan bahwa Komite Sekolah adalah wadah atau organisasi kerjasama orangtua siswa, tokoh masyarakat, kepala sekolah, dan guru yang tidak bersifat mencari keuntungan dan berperan dalam peningkatan kualitas proses dan hasil pendidikan. Komite Sekolah dan sekolah memiliki kemandirian masingmasing, tetapi tetap sebagai mitra yang harus saling bekerjasama.

Komite sekolah sebagai organisasi yang mewadahi aspirasi masyarakat, memiliki peran yang penting. Peran Komite Sekolah tidak dapat berdiri sendiri, melainkan peran yang saling terkait antara peran satu dengan peran lainnya. Dapat dijelaskan sebagai berikut:

1. Pemberi pertimbangan (advisory agency) dalam penentuan dan pelaksanaan kebijakan pendidikan di satuan Pendidikan

2. Pendukung (supporting agency) baik yang berwujud finansial, pemikiran, maupun tenaga kerja dalam penyelenggaraan pendidikan di satuan pendidikan;

3. Pengontrol (controlling agency) dalam rangka transparansi dan akuntabilitas penyelenggaraan dan keluaran pendidikan disatuan pendidikan;

4. Sebagai mediator antara pemerintah (eksekutif) dan dengan masyarakat di satuan pendidikan (Hasbullah, 2010: 93).

Bagian dari bentuk implementasi dilaksanakannya otonomi daerah dibidang pendidikan salah satunya berupa pemberian kewenangan manajemen pendidikan kepada sekolah yang kemudian dikenal dengan manajemen sekolah. Manajemen sekolah diatur dalam Keputusan Menteri Pendidikan Nasional Nomor053/U/2001 tentang pedoman penyusunan standar pelayanan minimal penyelenggaraan persekolahan dibidang Pendidikan Dasar dan Menengah.

Menurut pedoman standar pelayanan minmal TK, SD, SMP, SMU/SMK (2002), manajemen sekolah merupakan pengelolaan sekolah oleh kepala sekolah bersama dewan guru dan warga belajar lainnya secara mandiri, transparan, dan bertanggungjawab melaksanakan program sekolah untuk mencapai visi, misi, dan tujuan yang diamanatkan oleh masyarakat dan semua pihak yang berkepentingan terhadap pendidikan di sekolah yang bersangkutan.

Manajemen merupakan pendayagunaan melalui tahapan proses yang meliputi perencanaan, pengorganisasian, pengarahan, dan pengawasan. Menurut Stoner (dalam Bafadal, 2008:4), manajemen adalah proses perencanaan, pengorganisasian, dan penggunakan sumber daya organisasi lainnya agar mencapai tujuan organisasi yang telah ditetapkan.

Sarana pendidikan adalah peralatan dan perlengkapan yang secara langsung dipergunakan dan menunjang proses pendidikan, khususnya proses belajar mengajar, seperti gedung, ruang kelas, mejakursi, serta alat-alat dan media pengajaran. Adapun yang dimaksud dengan prasarana pendidikan adalah fasilitas yang secara tidak langsung menunjang jalannya proses pendidikan dan pengajaran, seperti halaman, kebun, taman kebun, jalan menuju sekolah, tetapi jika dimanfaatkan secara langsung untuk proses belajar mengajar, seperti taman sekolah untuk pengajaran biologi.

Menurut Mulyasa (2002:50) manajemen sarana dan prasarana pendidikan bertugas mengatur dan menjaga sarana dan prasarana pendidikan agar dapat memberikan kontribusi secara optimal dan berarti pada jalannya proses pendidikan. Menurut Suharsimi Arikunto (2008:131) Manajemen Kurikulum adalah segenap proses usaha bersama untuk memperlancar pencapaian tujuan pengajaran dengan titik berat pada usaha, meningkatkan kualitas interaksi 
belajar mengajar. Manajemen kurikulum adalah sebagai suatu system pengolaan kurikulum yang kooperatif, komprehensif, sistemik, dan sistematik, dalam rangka mewujudkan ketercapaian tujuan kurikulum.

Salah satu tugas utama sekolah adalah melaksanakan kegiatan pembelajaran berdasarkan kurikulum yang berlaku. Dengan demikian, pemahaman terhadap kurikulum sampai dengan strategi pelaksanaannya sangat penting. Meskipun kegiatan pembelajaran di kelas, labolatorium, lapangan dilaksanakan oleh guru tetapi peran kepala sekolah sangat penting, mulai dari perencanaan, koordinasi pelaksanaa, sampai evaluasinya.

Manajemen kesiswaan merupakan salah satu bidang operasional MBS. Manajemen kesiswaan adalah penataan dan aturan terhadap kegiatan dengan peserta didik, mulai masuk sampai dengan keluarnya peserta didik dari dari suatu sekolah. Manajemen kesiswaan bukan hanya terbentuk pencatatan data peserta didik melainkan meliputi aspek yang lebih luas yang secara operasional dapat membantu upaya pertumbuhan dan perkembangan peserta didik melalui proses pendidikan disekolah.

Manajemen kesiswaan bertujuan untuk mengatur berbagai kegiatan pembelajaran disekolah dapat berjalan dengan lancar, tertib, teratur, serta mencapai tujuan sekolah. Untuk mewujudkan tujuan tersebut bidang manajemen kesiswaan sedikitnya memiliki tiga tugas utama yang harus diperhatikan, yaitu penerimaan siswa baru, kegiatan kemajuan belajar, serta bimbingan dan pembinaan disiplin Mulyasa (2002:46).

Manajemen keuangan adalah manajemen terhadap fungsi-fungsi keuangan. Sedangkan fungsi keuangan merupakan kegiatan utama yang harus dilakukan oleh mereka yang bertanggung jawab dalam bidang tertentu. Keuangan di sekolah merupakan bagian yang penting karena setiap kegiatan memerlukan biaya. Manajemen keuangan diartikan sebagai tindakan ketatausahaan keuangan yang meliputi pencatatan, perencanaan, pelaksanaan, pertanggungjawaban, dan pelaporan (Depdiknas Ditjen Dikdasmen, 2000).
Dalam penyelenggaraan pendidikan, keuangan dan pembiayaan meupakan potensi yang sangat menentukan dan merupakan bagian yang tak terpisahkan dalam kajian manajemen pendidikan. Komponen keuangan dan pembiayaan pada suatu sekolah merupakan komponen produksi yang menentukan terlaksananya kegiatan-kegiatan prosesbelajar mengajar di sekolah bersama komponen-komponen keuangan dan pembiayaan ini perlu dikelola sebaikbaiknya, agar dana dapat dimanfaatkan secara optimal untuk menunjang tercapainya tujuan pendidikan.

Sumber keuangan dan pembiayaan pada suatu sekolah secara garis besar dapat dikelompokan atas tiga sumber, yaitu: (1) Pemerintah, baik pemerintah pusat, daerah maupun kedua-duanya, yang bersifat umum atau khusus dan diperuntukan bagi kepentingan pendidikan; (2) orang tua atau peseta didik; (3) masyarakat, baik mengikat maupun tidak mengikat. Proses pelaksanaan manajemen keuangan di SD yaitu: (a) perencanaan anggaran sekolah; (b) penerimaan pendapatan; (c) pengeluaran; (d) pertanggungjawaban; (e) pengawasan / pemeriksaan.

Personalia berasal dari bahasa asing yaitu personnel, maksudnya golongan dari masyarakat yang penghidupannya dilakukan denganb ekerja dalam kesatuan kerja pemerintah atau swasta. Di sekolah tingkat dasar, personalia adalah semua karyawan yang terlibat dalam penyelenggaraan pendidikan disekolah tingkat dasar, yaitu kepala sekolah, gurukelas, guru bidang studi, dan lain-lain. Manajemen personalia mencakup penetapan norma, standar, prosedur, pengangkatan, pembinaan, piñata laksana ,kesejahteraan, dan pemberhentian tenaga kependidikan sekolah agar melaksanakan tugas dan fungsinya dalam mencapai tujuan sekolah dasar. Kegiatan mengatasi ketenagaan edukatif dan non edukatif ini mencakup keseluruhan proses penyelenggaraan ketenagaan dengan menyajikan arus dokumen yang terdapat pada setiap tindakan dan kegiatan dalam bidang ketenagaan.

Hubungan sekolah dengan masyarakat pada hakekatnya merupakan suatu sarana 
yang sangat berperan dalam membina dan mengembangkan pertumbuhan pribadi peserta didik disekolah. Dalam ha lini, sekolah sebgai system social merupakan bagian integral dan system social yang lebih besar, yaitu masyarakat. Sekolah dan masyarakat mempunyai hubungan yang sangat erat dalam mencapai tujuan sekolah atau pendidikan secara efisien.

Secara lebih umum dikatakan bahwa hubungan sekolah dengan masyarakat diartikan sebagai suatu proses komunikasi dengan tujuan peningkatan pengertian warga masyarakat tentang kebutuhan dan praktik pendidikan serta berupaya dalam memperbaiki sekolah. Hubungan sekolah dengan masyarakat bertujuan antara lain untuk memajukan kualitas pembelajaran, dan pertumbuhan anak, memperoleh tujuan serta meningkatkan kualitas hidup dan kehidupan masyarakat, serta menggairahkan masyarakat untuk menjalin hubungan dengan sekolah.

Terdapat beberapa penelitian terdahulu yang meneliti hal serupa, seperti:

1. Widi Astuti dalam penelitiannya yang berjudul Partisipasi Komite Sekolah dalam Penyelenggaraan Kegiatan Ekstrakurikuler di SD Negeri se Kecamatan Godean.

Penelitian ini merupakan penelitian deskriptif kuantitatif. Subyek penelitian ini adalah Komite Sekolah yang terdiri dari wakil pihak sekolah, wakil dari pihak orang tua siswa, dan perwakilan dari masyarakat di Sekolah Dasar Negeri se Kecamatan Godean yang berjumlah 60 orang dimana pengambilan sampel menggunakan proposional sample. Data penelitian dikumpulkan dengan menggunakan angket/kuesioner dan studi dokumentasi. Teknis analisis data yang digunakan adalah teknis analisis deskriptif kuantitatif dengan persentase. Hasil penelitiannya mengatakan bahwa partisipasi Komite Sekolah dalam perencanaan kegiatan ekstra kurikuler sudah baik. Hal dalam bentuk sebagai berikut: dana $57.7 \%$, ide, anjuran, saran $70.6 \%$, tenaga $48.3 \%$, dan dalam bentuk alat pendukung $47.8 \%$ (Widi Astuti 2007:101).
2. Arifian Dwi Cahyanto dalam penelitiannya yang berjudul Peran Komite Sekolah Dalam MenjalankanTugas Pokok Dan Fungsi di SMA Negeri 1 Sanden.

Penelitiannya menggunakan pendekatan kualitatif yang hasil dari penelitianya secara keseluruhan peran Komite Sekolah dalam menjalankan tugas pokok dan fungsi di SMA Negeri 1 Sanden sudah berjalan, walaupun masih ada beberapa kekurangan. Peran Komite Sekolah dalam menjalankan tugas pokok dan fungsi di SMA Negeri 1 Sanden dapat dilihat ketika rapat koordinasi dan pertemuanpertemuan rutin, seperti dalam penyusunan dan pengesahan RAPBS, program sekolah, perencanaan pembangunan, dan sarana prasarana.

3. Khoiril Mawahib, dalam penelitiannya yang berjudul Peran Komite Madrasah dalam Pengembangan MAN Maguwoharjo Sleman Yogyakarta

Hasil penelitiannya menunjukkan: (1) Komite madrasah MAN Maguwoharjo Sleman telah dibentuk sejak tahun pelajaran 2001-2002. Kepengurusan komite madrasah dinilai cukup representatif karena sudah memasukkan unsur pemerhati dan praktisi pendidikan, tokoh agama dan tokoh masyarakat, kalangan dunia usaha, alumni, pihak madrasah dan mayarakat secara umum. (2) Program yang dilaksanakan komite Madrasah Aliyah Negeri Maguwoharjo belum optimal. Komite tidak punya inisiatif. Selama ini madrasah yang menawarkan program kepada komite Madrasah Aliyah Negeri Maguwoharjo. (3) Komite madrasah di MAN Maguwoharjo Sleman telah berperan dalam pengembangan madrasah. Hal ini terbukti antara lain: (a) Memfasilitasi peserta didik dalam bidang ekstra kurikuler (b) Bekerjasama dengan madrasah membuka jurusan baru, yaitu jurusan agama (c) Mengusulkan workshop untuk guru, (d) Memberi pertimbangan terhadap kebijakan pendidikan MAN Maguwoharjo Sleman (e) Mengajak masyarakat untuk berperan serta dalam mengembangkan madrasah. (4) Komite 
madrasah di Madrasah Aliyah Negeri Maguwoharjo sudah lima tahun tidak mengalami reorganisasi.

Serangkaian penelitian terdahulu diatas menunjukkan bahwa berubahnya paradigma pendidikan yang berbasis sekolah dan menjadi tanggung jawab pemerintah daerah dan seluruh stakeholder mengharuskan masyarakat untuk ikut ambil bagian atau berpartisipasi dalam pendidikan Dengan adanya wadah partisipasi masyarakat melalui lembaga otonomi yakni Komite Sekolah mengharuskan untuk dapat berfungsi semaksimal mungkin sesuai Keputusan Menteri Pendidikan Nasional Nomor 044/U/2002.

Peran Komite Sekolah dalam melaksanakan MBS adalah wujud kepedulian masyarakat terhadap pendidikan. Selain kegiatan-kegiatan non akademik yang dilakukan Komite Sekolah, ada juga kegiatan akademik. Perkembangan peran dan fungsi yang terjadi pada komite sekolah itu tidak hanya dirasakan oleh pihak sekolah melainkan juga dirasakan oleh orang tua siswa/masyarakat. Keberadaan Komite Sekolah memberikan kebaikan bagi semua, oleh karena itu kerjasama tidak hanya dijalin dalam lingkup intern sekolah saja. Komite MTs Negeri Karang Intan juga bersinggungan dengan masyarakat.

\section{Hasil Penelitian dan Pembahasan}

Berdasarkan pada penelitian yang sudah dilakukan, peran dari komite sekolah berdasarkan masing-masing bidangnya dapat dijabarkan sebagai berikut:

1. Peran Komite Sekolah dalam Manajemen Sarana Prasarana

Dalam manajemen sarana prasarana di MTs Negeri Karang Intan ada 3 hal pokok yang dilakukan yaitu pengadaan, perawatan, dan penataan. Kebijakan manajemen sarana prasarana selanjutnya diimplementasikan dalam bentuk: (1) perawatan alat-alat perlengkapan sekolah; (2) pengadaan alat belajar; (3) pengadaan gedung untuk ruang kelas; (4) perawatan komputer, taman sekolah, kamar mandi, dan listrik. Sarana prasarana di MTs Negeri Karang Intan sudah cukup lengkap, pengadaan media yang diperlukan sekolah selalu koordinasi dengan Komite Sekolah disesuaikan dengan kebutuhannya. Keadaan sarana prasarana yang lengkap, memadai, dan terawat dengan baik tidak terlepas dari campur tangan Komite Sekolah, walaupun komite sekolah hanya sebatas menyetujui program yang diajukan sekolah. Dalam hal manajemen sarana prasarana, komite tidak pernah ikut dalam pengelolaannya.

Penentuan kebijakan dalam manajemen sarana prasarana diputuskan oleh sekolah bersama komite sekolah, Keterbatasan dana dari pemerintah (BOS), membuat MTs Negeri Karang Intan tidak dapat melakukan perbaikan besar maupun penambahan fasilitas sekolah tanpa partisipasi orangtua siswa. Hal tersebut menunjukkan bahwa komite sekolah secara langsung dilibatkan oleh sekolah dalam penyusunan manajemen bidang sarana prasarana.

Komite Sekolah berperan dalam memberikan masukan setiap rapat. Masukan-masukan tersebut ditampung sekolah sebagai pertimbangan dalam mengambil keputusan. Sekolah memposisikan komite sekolah sebagai badan mediasi yaitu menetukan kebijakan bersama mengembangkan kualitas maupun mutu sekolah dalam penyelenggaraan pendidikan. Keterlibatan komite sekolah ini bertujuan agar manajemen sarana prasarana yang disusun oleh sekolah dapat didukung pula oleh seluruh orangtua siswa, baik dukungan moral maupun material.

Berdasarkan pemaparan data diatas dapat diketahui bahwa peran Komite Sekolah dalam hal manajemen sarana prasarana hanya sebatas mendukung program sekolah dan sesekali dapat menjadi mediator antara orang tua dengan sekolah apabila sekolah memerlukan sesuatu untuk pengadaan sarana prasarana. Namun dalam hal pengelolaan sarana prasarana komite sekolah tidak pernah berperan aktif.

2. Peran Komite Sekolah dalam Manajemen Kurikulum 
Manajemen kurikulum di MTs Negeri Karang Intan meliputi: (1) pusat, bahwa di MTs Negeri Karang Intan menggunakan kurikulum dari pusat; (2) sosialisasi, kurikulum yang baru dari pusat disosialisasikan ke warga sekolah; (3) musyawarah, sekolah melakukan koordinasi dengan komite; (4) pelaksanaan pengajaran dilaksanakan sesuai dengan program kurikulum dan program pembelajaran yang diwujudkan dalam kegiatan ekstrakurikuler; dan (5) Evaluasi, penilaian program pengajaran.

MTs Negeri Karang Intan menggunakan dua kurikulum, yaitu kurikulum 2013 dan kurikulum 2006 (KTSP). Kurikulum 2013 sudah berjalan semenjak ada keputusan dari pemerintah pusat. Sekolah selalu bermusyawarah dengan komite terkait kurikulum yang digunakan sekolah. Namun kenyataannya peran Komite Sekolah dalam manajemen kurikulum dirasakan tidak terlibat secara langsung dalam manajemen kurikulum yaitu mendukung kurikulum yang digunakan oleh sekolah. Komite sebagai badan pengontrol tidak pernah mengawasi dan menayakan sejauh mana kurikulum berjalan dan memberikan masukan tentang kegiatan-kegiatan yang mendukung anak didik untuk dapat menyalurkan hobinya melalui kegiatan ekstrakulikuler. Komite sekolah sebagai mediator hanya menjadi penengah ketika terjadi permasalahan dalam rapat dan perantara orang tua siswa dengan guru mengenai cara penyampaian pelajaran atau materi pelajaran.

3. Peran Komite Sekolah dalam Manajemen Kesiswaan

Manajemen kesiswaan di MTsN Karang Intan terkelola dengan baik dimulai dari penerimaan siswa baru sampai kelulusan. Penerimaan siswa baru di MTs Negeri Karang Intan sudah dikelola sedemikian rupa mulai dari perencanaan penentuan daya tampung sekolah atau jumlah siswa baru yang akan diterima, yaitu dengan mengurangi daya tampung dengan anak yang tinggal kelas atau mengulang. Setelah siswa baru diterima lalu dilakukan pengelompokan dan orientasi sehingga secara fisik, mental dan emosional siap untuk mengikuti pendidikan di sekolah.

Dalam proses manajemen kesiswaan Komite Sekolah terbatas hanya memberi masukan apabila diminta oleh sekolah terkait prestasi anak didiknya. Komite Sekolah berusaha mencukupi semua kebutuhan siswa khususnya di dalam manajemen kesiswaan ini untuk memotivasi anak-anaknya agar dapat berprestasi. Dalam menjalankan perannya Komite Sekolah jarang mengadakan rapat dengan guru dan kepala sekolah terkait program sekolah untuk memajukan pendidikan peserta didik sesuai bakat dan minat peserta didik.

Dalam proses manajemen kesiswaan Komite Sekolah jarang bahkan untuk anggota komite yang lain terkesan acuh dalam memperhatikan prestasi anak didiknya. Dalam menjalankan perannya Komite Sekolah sesekali mengadakan agenda rapat dengan dewan kelas dan kepala sekolah untuk memajukan pendidikan anaknya sesuai bakat dan minat peserta didik.

Sebagai lembaga pemberi pertimbangan, Komite Sekolah memberikan pertimbangan berupa masukan pada saat rapat diadakan, sehingga sekolah mendapatkan masukan-masukan untuk lebih di pertimbangkan. Komite sekolah diminta untuk kritis dalam memberikan masukan, sehingga tidak hanya mengikuti saran ataupun kebijakan yang di tawarkan oleh sekolah. Komite Sekolah mendukung penuh adanya ekstrakulikuler walaupun dalam pengelolaannya tidak pernah aktif dalam memberikan pendanaan kegiatan ekstrakurikuler serta dalam hal memberikan penghargaan bagi siswa yang berprestasi. Sebagai badan pengontrol dalam proses manajemen kesiswaan, peran Komite Sekolah yaitu melakukan kontrol datang kesekolah apabila diminta oleh pihak sekolah.

4. Peran Komite Sekolah dalam Manajemen Keuangan

Sumber keuangan MTs Negeri Karang Intan berasal dari DIPA Madrasah dan 
Bantuan Operasional Sekolah saja dan tidak ada dana wajib yang berasal dari wali murid. Sekolah harus pintar mengatur keuangan agar pemasukan dan pengeluaran bisa seimbang. Komite Sekolah juga memberikan rekomendasi atas penggunaan dana yang ada disesuaikan dengan kebutuhan sekolah. Komite Sekolah mendukung sekolah melakukan penggalangan dana dan mengelola dana keuangan yang berasal sumbangan sukarela orangtua siswa, walaupun itu hanya dilakukan setahun sekali pada tahun ajaran baru. Selain itu berbicara mengenai RABPS, Komite Sekolah dilibatkan sekolah dalam merencanakan RABPS. Namun Komite hanya sebatas memberikan masukan dan mengesahkan dalam penyusunan RAPBS. Masukan yang diberikan hanya secara umum. Secara umum disini, maksudnya adalah masukan yang hanya berupa usulan-usulan yang diberikan oleh pihak Komite Sekolah kepada pihak sekolah tanpa adanya paksaan untuk dilaksanakan oleh sekolah. Ketika RAPBS telah disetejui oleh Komite Sekolah, sekolah beserta Komite Sekolah bertugas untuk menyampaikan hasilnya kepada wali murid dan masyarkat.

Komite Sekolah belum pernah menentukan kebijakan anggaran bersama sekolah. Selain itu peran komite hanya mendukung penuh dengan apa yang sudah menjadi kesepakatan bersama. Dukungan yang berikan yang bersifat formal diberikan ketika ada pertemuan resmi seperti pendanaan, fasilitas sekolah dan kebutuhan sekolah. Sehingga Komite Sekolah dalam memberikan dukungannya bersifat transparan dan semua pihak mengetahui. Sedangkan dukungan yang bersifat non formal berupa motivasi maupun support kepada kepala sekolah, guru, karyawan, dan peserta didik. Sedangkan kontrol yang dilakukan Komite Sekolah terhadap masalah anggaran dan keuangan sekolah belum pernah dilakukan, seperti misalnya dengan melihat laporan-laporan keuangan dari segi penggunaan anggaran, jumlah anggaran, dan lain- lain.
Dari pernyataan diatas bahwa Komite Sekolah belum berperan secara aktif dalam memberikan pertimbangan, dukungan, pengawasan, dan mediator. Seluruhnya dalam manajemen keuangan dilakukan oleh pihak sekolah saja, komite sekolah tidak pernah melakukan pengawasan, kecuali diminta oleh pihak sekolah.

5. Peran Komite Sekolah dalam Manajemen personalia

Manajemen personalia di MTsN Karang Intan itu meliputi (a) perencanaan ketenagaan (b) rekrutmen (c) pengembangan (d) pembinaan (e) penilaian. Manajemen personalia di MTs Negeri Karang Intan dibagi menjadi 2 yaitu ketenagaan pegawai dan sumber daya manusia dan peningkatan SDM. Dalam ketenagaan pegawai dan SDM antara lain perekrutan tenaga pustakawan, guru TIK, tenaga TU, dan guru ekstrakurikuler.

Penyusunan manajemen personalia disusun oleh sekolah dan Komite Sekolah hanya memberikan masukan di setiap awal tahun, tentunya disesuaikan dengan kebutuhan tenaga yang ada dan disesuaikan anggaran keuangan sekolah. Untuk peningkatan SDM pegawai dan tenaga pengajar dilakukan melalui kegiatan supervisi kelas, KKKM, MGMP, diklat, seminar, workshop, serta studi banding.

Komite Sekolah menyerahkan sepenuhnya kepada sekolah untuk mengurusi penerimaan tenaga pendidik. Komite Sekolah beranggapan bahwa sekolah mempunyai kewenangan penuh untuk menerima ataupun tidak menerima guru yang ingin mendaftar di sekolah. Karena sudah mempercayakan sepenuhnya mengenahi penerimaan tenaga pendidik kepada sekolah. Sebagai badan pendukung (supporting agency), Komite Sekolah telah melaksanakan beberapa hal meliputi (1) mendukung sekolah untuk menanggulangi kekurangan guru; (2) mendukung sekolah dalam hal tenaga kependidikan non guru untuk mengisi kekurangan di sekolah; (3) mendukung 
sekolah dalam meningkatkan sarana dan prasarana; (4) Memberikan dukungan dalam hal penambahan anggaran di sekolah. Berkaitan dengan pemantauan tenaga pendidik, komite sekolah belum pernah melakukan pemantauan tenaga pendidik dan kependidikan, baik di setiap akhir tahun pelajaran maupun pada waktu awal tahun ajaran baru. Pada akhir tahun pelajaran tersebut, sekolah bersama dengan Komite Sekolah dan wali murid menyelenggarakan rapat untuk menyampaikan hasil pendataan tenaga pendidik yang telah dilaksanakan selama satu tahun.

6. Peran Komite Sekolah dalam Manajemen Hubungan Masyarakat

Manajemen Hubungan masyarakat di MTs Negeri Karang Intan bertujuan untuk menjaga komunikasi yang baik antara sekolah dengan lembaga terkait, khususnya orang tua siswa. Hal ini menunjukkan bahwa untuk merealisasikan program sekolah khususnya manajemen hubungan masyarakat diperlukan bantuan dari Komite Sekolah sebagai pelaksana teknis dalam setiap kegiatannya. Program humas di MTs Negeri Karang Intan telah dimusyawarahkan pihak sekolah dengan Komite Sekolah sebagai wakil orangtua siswa. Namun keterlibatan Komite Sekolah dalam manajemen hubungan masyarakat hanya sebagai mediator apabila ada hal-hal yang tidak diinginkan dalam hubungan antara sekolah dengan orang tua siswa maupun dengan masyarakat.

Peran Komite Sekolah sebagai pendukung dalam manajemen humas tidak dapat dipisahkan dari peranan orangtua yang ada disetiap kelas , karena dalam praktiknya Komite Sekolah tidak dapat melakukan perannya sendiri disebabkan terbatasnya jumlah pengurus komite.

Berdasarkan seluruh pemaparan data dapat dimaknai bahwa adanya peran Komite Sekolah dalam bidang manajemen hubungan masyarakat, khususnya yang terkait dengan peran komite sekolah sebagai mediator menjadikan komunikasi antara sekolah dan lembaga-lembaga terkait dapat terjalin dengan harmonis. Orangtua siswa juga mendapatkan informasi tentang seluruh program sekolah. Sekolah, Komite Sekolah, dan masyarakat secara beriringan saling bantu membantu agar pembelajaran siswa dapat berkualitas dan berdampak pada meningkatnya prestasi siswa.

\section{Kesimpulan}

Kesimpulan dari hasil penelitian ini dapat diuraikan sebagai berikut :

1. Peran komite sekolah dalam bidang manajemen sarana dan prasarana
a. Komite Sekolah memberikan pertimbangan berupa masukan- pertimbangan/advisory agency) masukan pada saat rapat (pemberi
b. Komite mendukung dalam penambahan dana secara sukarela (pendukung/supporting agency)
c. Komite jarang mengawasi dan mengkontrol sarana prasarana sekolah (pengontrol/controlling agency)
d. Komite menengahi bila terjadi perdebatan, dan mengajak bermusyawarah dalam penyelesainya (mediator)

2. Peran komite sekolah dalam bidang manajemen keuangan

a. Komite tidak terlibat dalam memberikan pertimbangan berupa masukan dan ikut mengesahkan RAPBS (pemberi pertimbangan/ advisory agency)

b. Komite mendukung penuh dan berusaha mencari dalam penambahan dana (pendukung/ supporting agency)

c. Komite tidak pernah melakukan kontrol dengan melihat langsung buku keuangan milik bendahara (pengontrol/ controlling agency)
d. Komite sering mengadakan musyawarah (mediator)

3. Peran komite sekolah dalam bidang manajemen kesiswaan
a. Komite memberikan masukan- masukan dan terlibat dalam pembuatan visi-misi sekolah (pemberi pertimbangan/advisory agency) 
b. Komite mendukung program sekolah, ektrakulikuler, dan pencarian dana tambahan. (pendukung/supporting agency)

c. Komite tidak melakukan perannya sebagai peng ontrol langsung kelapangan (pengontrol/controlling agency)

d. Komite menjembatani sekolah dan masyarakat dan memberikan mediasi pada saat rapat serta memberikan solusi (mediator)

4. Peran komite sekolah dalam bidang manajemen kurikulum

a. Komite tidak pernah memberikan masukan yang terkait dengan manajemen kurikulum (pemberi pertimbangan/advisory agency)

b. Komite mendukung kurikulum yang dipakai disekolah, dan mendukung adanya pembekalan terhadap guru (pendukung/supporting agency)

c. Komite tidak pernah mengawasi sejauh mana kurikulum berjalan (pengontrol/controlling agency)

d. Komite belum berperan aktif sebagai mediator dalam manajemen kurikulum (mediator)

5. Peran komite sekolah dalam bidang manajemen personalia

a. Komite memberikan saran terkait manajemen personalia apabila diminta sekolah (pemberi pertimbangan/advisory agency)

b. Komite mendukung peningkatan mutu pegawai melalui pelatihan (pendukung/supporting agency)

c. Komite hadir langsung Kelapangan apabila ada permintaan dari sekolah (pengontrol/controlling agency)

d. Komite pernah melakukan mediasi pada guru yang bermasalah dengan pihak sekolah (mediator)

6. Peran komite sekolah dalam bidang manajemen hubungan masyarakat

a. Komite terlibat dalam memberikan pertimbangan berupa masukan dalam manajemen humas, namun tidak terlibat dalam memutuskan program humas (pemberi pertimbangan/advisory agency)

b. Komite mendukung penuh dalam manajemen humas (pendukung/supporting agency)

c. Komite tidak pernah melakukan kontrol dalam manajemen humas (pengontrol/controlling agency)

d. Komitesering mengadakan musyawarah dan menjadi mediator dalam komunikasi antara orang tua dan sekolah. (mediator)

\section{DAFTAR PUSTAKA}

Bafadal,I. 2008. Manajemen Perlengkapan Sekolah:Teori dan aplikasinya. Jakarta: Bumi Aksara.

Cahyanto Arifian Dwi. 2012. Peran Komite Sekolah dalam menjalankan tugas pokok dan fungsidi SMA Negeri 1 Sanden. Skripsi.

Hasbullah. 2010. Otonomi Pendidikan: Kebijakan Otonomi Daerah dan Implikasinya Terhadap Penyelenggaraan Pendidikan. Jakarta: Rajawali.

Moleong. Lexy J. 2002. Medologi Penelitian Kualitatif. Bandung: Remaja Rosda Karya.

Kemendiknas. 2002. Keputusan Menteri Pendidikan Nasional Republik Indonesia No.044/U/2002 tentang Dewan Pendidikan dan Komite Sekolah. Jakarta: Depdiknas.

Majid, A. 2009. Perencanaan Pembelajaran. Bandung: PT. Remaja Rosdakarya.

Mulyasa. 2007. Manajemen Berbasis Sekolah. Bandung: PT Remaja Rosdakarya

---. 2007. Medologi Penelitian Kualitatif. Bandung: Remaja Rosda Karya.

Peraturan Pemerintah Republik Indonesia Nomor 17 tahun 2010 tentang Pengelolaan dan Penyelenggaraan Pendidikan. Jakarta: Departemen Pendidikan Nasional.

Rodliyah. 2013. Partisipasi masyarakat dalam pengambilan keputusan perencanaan di sekolah. Yogyakarta: PustakaPelajar.

Rusman. 2008. Manajemen Kurikulum. Bandung: PT RajaGrafindo Persada. 
S.Nasution. 2003. Metode Penelitian Naturalistik- Kualitatif. Cetakan III, Bandung: PT. Tarsito.

Sri Renani Pantjastuti. 2008. Komite Sekolah: Sejarah dan Prospeknya DiMasa Depan. Yogyakarta: Hikayat Publishing.

Sugiyono. 2007. Metode Penelitian Kuantitatif dan Kualititatif dan R \& D. Bandung: Alfabeta.

Suharsimi Arikunto. 2005. Manajemen Penelitian. Jakarta: RinekaCipta.
Syaiful Sagala. 2007. Manajamen Strategik dalam Peningkatan Mutu Pendidikan. Bandung: Alfabeta.

Tim Dosen Administrasi Pendidikan Universitas PendidikanIndonesia. 2009. Manajemen Pendidikan. Bandung: Alfabeta

Widi Astuti. 2007 .Partisipasi Peran Komite Sekolah Dalam Penyelenggaraan Kegiataan Ekstra kurikuler di SD Negeri Se Kecamatan Godean. Tesis 